\section{Pattern and determinants of obesity among adolescent females in private and public schools in the Olorunda Local Government Area of Osun State, Nigeria: a comparative study}

\author{
Ebenezer Olubanji Ojofeitimi, ${ }^{1}$ \\ Adenike Iyanuoluwa Olugbenga-Bello, ${ }^{1}$ \\ Daniel Adebode Adekanle, ${ }^{2}$ \\ Adeleye A. Adeomi ${ }^{3}$ \\ 1Department of Community Medicine, \\ Faculty of Clinical Sciences, College of \\ Health Sciences, Ladoke Akintola \\ University of Technology (LAUTECH), \\ Osogbo, Osun State, Nigeria; \\ ${ }^{2}$ Department of Obstetrics and
} Gynaecology, Faculty of Clinical Sciences, College of Health Sciences, Ladoke Akintola University of Technology (LAUTECH), Osogbo, Osun State, Nigeria; ${ }^{3}$ Department of Community Medicine, Ladoke Akintola University of Technology (LAUTECH) Teaching Hospital, Osogbo, Osun State, Nigeria

\section{Abstract}

The prevalence of obesity has continued to rise at an alarming rate worldwide to such an extent that it has been described as a global epidemic. Our study aims to investigate the pattern and determinants of obesity among adolescent females in private and public schools in the Olorunda Local Government Area of Osun State, Nigeria. This is a crosssectional descriptive study. Using the multistage sampling technique, 520 pre-tested, semi-structured questionnaires were administered to 257 girls from private schools and 263 girls from public schools. Most of the respondents from private schools (65.2\%) had good knowledge about obesity and related matters while most of those from public schools (65.9\%) had poor knowledge. The dietary practice of the majority of the girls from private schools $(60.2 \%)$ was unhealthy while most of the girls from public schools (68.7\%) had healthy dietary practices. Most of the respondents from private schools (64.2\%) lived sedentary lifestyles while most from public schools (64.0\%) lived active lifestyles. Using the BMI, the majority of the girls from private schools were underweight (52\%), 10 (4.0\%) were overweight and $3(1.2 \%)$ were obese. For public schools, the majority (55.4\%) fell within the normal group, 6 (2.3\%) were overweight and none was obese. The prevalence of being over- weight and of obesity was higher among the girls in private schools than among girls attending public schools. We concluded that awareness should be created to promote a healthy balance of food, drink and physical activity within and outside the school.

\section{Introduction}

The World Health Organization (WHO) defined adolescence as the period from 10 to 19 years of age; ${ }^{1}$ it is the transitional period between childhood and adulthood. ${ }^{2}$ However, the National Adolescent Health Policy in Nigeria viewed ages 10 to 24 years as a more appropriate range for adolescence. ${ }^{3}$ It has been found that the rapid changes in physical growth and psychological development have placed adolescents as a nutritionally vulnerable group with unhealthy eating behaviours. , $^{14-6}$

The prevalence of obesity has continued to rise at an alarming rate worldwide to such an extent that it has been described as a global epidemic and it has even replaced under-nutrition as the most common public health concern for infants and children. ${ }^{7}$ This increased prevalence, which was initially more marked in developed countries, ${ }^{8-10}$ has become a global concern. ${ }^{11-14}$ Although the aetiology of obesity is rather complex, increased intake of fast foods, replacement of the traditional high fibre diet with Western diets with high sugar and fats and the tendency for a more sedentary lifestyle with the advent of cars are believed to contribute to this epidemic of childhood obesity. ${ }^{15-18}$

Obesity is a disease process associated with the development of serious medical complications and increased mortality in adulthood. Obesity is also a risk factor associated with cardiovascular disease, atherosclerosis, diabetes and breast, colonic, endometrial and prostate cancers..$^{10,19-20}$ Adolescent obesity is thought to be associated with some psychological problems like low self esteem, feeling of inadequacy, anxiety, social dysfunction, depression and moodiness; all of which affect the personality of the adolescents..$^{21,22} \mathrm{~A}$ study reported that girls who are overweight or obese are prone to developing high-risk behaviours such as smoking and drinking alcohol, and are also less likely to engage in physical activities and exercise programmes that promote energy expenditure..$^{23}$

In the United States of America (USA), the incidence of obesity in adolescents rose from $11 \%$ in 1984 to $25 \%$ in 1998 , with AfricanAmerican girls having a $50 \%$ greater prevalence than White girls. ${ }^{10,24}$ In Australia, at least one in five children and adolescents are obese or overweight, with a continuous rise in
Correspondence: Adenike Iyanuoluwa,

Olugbenga-Bello, Department of Community Medicine, Faculty of Clinical Sciences, College of Health Sciences, PMB 4400, Osogbo, Osun State, Nigeria.

E-mail: nike_bello@yahoo.com

Key words: pattern, prevalence, determinants, obesity, adolescents, girls, overweight.

Acknowledgements: the authors wish to acknowledge the cooperation of the staff of Olorunda Local Government for helping the researchers in providing necessary information and the medical students who were trained as research assistants to help in the data collection.

Received for publication: 15 October 2010. Accepted for publication: 20 January 2011.

This work is licensed under a Creative Commons Attribution 3.0 License (by-nc 3.0).

(C) Copyright E.O. Ojofeitimi et al., 2011

Licensee PAGEPress, Italy

Journal of Public Health in Africa 2011; 2:e11

doi:10.4081/jphia.2011.e11

prevalence. $^{25}$ The prevalence of being overweight and of obesity in Canadian children aged 7 to 13 years has also doubled and tripled, respectively, since $1981 .{ }^{8}$ In the United Arab Emirates(UAE), recent research suggested that the prevalence of childhood obesity is increasing dramatically, already surpassing the high levels of obesity found among children and adolescents in the USA and Europe. ${ }^{26,27}$ In Nigeria, data on the prevalence of being overweight and of obesity are few and scattered. A study by Omolola et al. in southwestern Nigeria ${ }^{28}$ reported no adolescent to be neither overweight nor obese among the rural dwellers studied. Another study in Lagos, Nigeria ${ }^{29}$ reported overall prevalence rates of being overweight and of obesity in the urban and rural areas to be $3.7 \%$ and $0.4 \%$, and $3.0 \%$ and $0.0 \%$, respectively. Furthermore, the prevalence rates of obesity and being overweight in a study carried out in Cross River, Nigeria were $1.7 \%$ and $6.8 \%$, respectively. ${ }^{30}$

The adolescents, however, are considered as the age group with the least mortality. ${ }^{31}$ Despite increased concerns for adolescent health worldwide, adolescence has not been considered to be a high priority stage for nutritional needs and intervention.1,32 Therefore, our study was carried out to assess the pattern and determinants of obesity among adolescent females in private and public schools in the Olorunda Local Government Area (LGA) in Osun State, Nigeria, with a view to compare the socio-economic characteristics of the respondents and the relationship of this to the prevalence of obesity among them. 


\section{Materials and Methods}

The study was carried out in the Olorunda LGA, which is one of the 30 LGAs in Osun State, Nigeria. There are a total of 27 secondary schools in the LGA; 13 public and 14 private secondary schools, with a total number of 16,450 students. The target population was the female students aged between 10 and 19 years.

This is a comparative, cross-sectional study. The minimum sample size for each sub-sample was determined using $n=2 z^{2} p q / d^{2}[z=c o n-$ fidence limits (1.96), $p=$ prevalence, $q=1.0-p$, $\mathrm{d}=$ degree of accuracy desired (0.05)] for testing differences between two sub-samples. ${ }^{33}$ The calculated minimum sampling size for either group, taking prevalence (p) of obesity from previous studies to be $4 \%,{ }^{29}$ was 118 . However, to take care of non-response and to increase representativeness, a total of 520 respondents from two public and three private secondary schools, 257 from private schools and 263 from public schools, were selected using the multistage sampling technique.

The data were collected using pre-tested, semi-structured questionnaires, which were either self-administered or administered by trained research assistants. The questionnaire was drafted using relevant literature and also reviewed by experts in Public Health Nutrition. To further ensure validity and reliability, independent persons translated the questionnaire to Yoruba and back to English; pre-testing was done in a public secondary school in Ofatedo, Egbedore Local Government Area. A total of 50 students were interviewed, after which necessary adjustments were made before the instrument was used for the main study.

Anthropometric measurements were used to determine obesity. This involved measuring the weight with a weighing scale and height with measuring tapes. The scoring system was done for knowledge about obesity and related matters, dietary practices and lifestyles. For knowledge, the mean score was 2.69 in a maximum score of 8 ; thus, any score less than 2.69 was rated as poor knowledge and 2.69 and above was rated as good knowledge. From a maximum of 17 for dietary practices, a score of 0 to 6.38 was rated as unhealthy practices and a score above 6.38 (the mean score) was rated as healthy practices. Sedentary lifestyle was from a score of 0 to 2.73 (the mean score) and active lifestyle was from a score of 2.73 to 7 (the maximum score).

The questionnaires were manually sorted, entered onto a computer and analysed using Statistical Package for Social Sciences (SPSS) version 15. Bivariate analysis was performed with appropriate test statistics and the P-value set at $\mathrm{P} \leq 0.05$.

\section{Results}

Of the 520 respondents, 257 (49.4\%) were from private schools while 263 (50.6\%) were from public schools. The majority of the respondents between 10 and 14 years (163, $58.2 \%$ ) were from private schools with a mean age of $13.8+1.79$ years while for those between 15 and 19 years, the majority (146, 60.8\%) were from public schools with a mean age of $14.8+1.97$ years. For ethnicity, $245(49.6 \%)$ and 249 (50.4\%) were Yorubas; 11 (47.8\%) and 12 (52.2\%) were from other ethnic groups from private and public schools, respectively. The majority of respondents from monogamous family settings $(226,57.4 \%)$ were from private schools while the majority of those from polygamous family settings $(88,77.5 \%)$ were from public schools. Concerning the occupation of parents, fathers who were skilled workers were found more among girls in private schools $(158,66.7 \%)$ and unskilled fathers were found more among girls in public schools (113, $81.9 \%)$. Skilled mothers were also found more among girls attending private schools (113, 73.4\%) while unskilled mothers were found more among public school attendees (190, $74.8 \%$ ). More of those girls who lived with their parents were at private schools (240, $52.5 \%$ ) while most of those who lived with relatives/guardians were attending public schools (37, 71.2\%). Christians were found more in private schools $(161,66.5 \%)$ and Muslims were found more in public schools (176, 65.2\%).

As shown in Table 1, there was a significant association between the school type and most of the socio-demographic characteristics: age $\left(\chi^{2}=18.76 ; \quad \mathrm{P}=0.0001\right), \quad$ family setting $\left(\chi^{2}=42.04 ; \mathrm{P}=0.0001\right)$, father's occupation $\left(\chi^{2}=82.81 ; \mathrm{P}=0.0001\right)$, mother's occupation $\left(\chi^{2}=124.76 ; \quad \mathrm{P}=0.0001\right)$ and religion $\left(\chi^{2}=53.32 ; \mathrm{P}=0.0001\right)$.

In Table 2, obesity/overweight in any of the parents or siblings is seen to occur more among girls attending public schools: 94 (60.6\%) and 57 (60.6\%), respectively. Girls who had one to four siblings were found more in private schools $(199,65.2 \%)$ while those with more than four siblings were found more in public schools (140, 73.3\%). Good knowledge about obesity was demonstrated by more respondents from private schools $(167,65.2 \%)$ while poor knowledge was found more among girls in public schools (172, 65.9\%). Active lifestyles and healthy dietary practices, however, were demonstrated more among respondents in public schools: $167(64.5 \%)$ and 180 (63.8\%), respectively. There were also significant associations between school type and the risk factors for obesity, including history of obesity in parents $\left(\chi^{2}=9.52 ; \mathrm{P}=0.002\right)$, knowledge about obesity $\left(\chi^{2}=50.12 ; \mathrm{P}=0.0001\right)$, dietary practice $\left(\chi^{2}=43.48 ; \mathrm{P}=0.0001\right)$ and activities/lifestyle $\left(\chi^{2}=41.15 ; \mathrm{P}=0.0001\right)$.

Table 3 shows the respondents who felt that they were too fat were found more in private

Table 1. Socio-demographic characteristics of respondents.

\begin{tabular}{|c|c|c|c|c|c|}
\hline \multirow[t]{2}{*}{ Variable } & \multicolumn{3}{|c|}{ Frequency (percentage) } & \multirow[t]{2}{*}{$\chi^{2}$} & \multirow[t]{2}{*}{$P$} \\
\hline & Private & Public & Total & & \\
\hline \multicolumn{6}{|l|}{ Age group (yr) } \\
\hline $10-14$ & $163(58.2)$ & $117(41.8)$ & $280(100.0)$ & \multirow[t]{2}{*}{18.76} & 0.0001 \\
\hline $15-19$ & 94 (39.2) & $146(60.8)$ & $240(100.0)$ & & Significant \\
\hline \multicolumn{6}{|l|}{ Class } \\
\hline Junior secondary & $122(49.0)$ & $127(51.0)$ & $249(100.0)$ & \multirow[t]{2}{*}{0.21} & 0.885 \\
\hline Senior secondary & $134(49.6)$ & $136(50.4)$ & $270(100.0)$ & & Not significant \\
\hline \multicolumn{6}{|l|}{ Ethnic groups } \\
\hline Yoruba & $245(49.6)$ & $249(50.4)$ & $494(100.0)$ & \multirow[t]{2}{*}{0.028} & 0.868 \\
\hline Others & $11(47.8)$ & $12(52.2)$ & $23(100.0)$ & & Not significant \\
\hline \multicolumn{6}{|l|}{ Family setting } \\
\hline Monogamous & $226(57.4)$ & $168(42.6)$ & $394(100.0)$ & \multirow[t]{2}{*}{42.04} & 0.0001 \\
\hline Polygamous & $25(22.5)$ & $86(77.5)$ & $111(100.0)$ & & Significant \\
\hline \multicolumn{6}{|l|}{ Father's occupation } \\
\hline Skilled & $158(66.7)$ & $79(33.3)$ & $237(100.0)$ & \multirow[t]{3}{*}{82.81} & 0.0001 \\
\hline Semi-skilled & $70(52.6)$ & $63(47.4)$ & $133(100.0)$ & & Significant \\
\hline Unskilled & $25(18.1)$ & $113(81.9)$ & $138(100.0)$ & & \\
\hline \multicolumn{6}{|l|}{ Mother's occupation } \\
\hline Skilled & $113(73.4)$ & $41(26.6)$ & $154(100.0)$ & \multirow{3}{*}{124.76} & 0.0001 \\
\hline Semi-skilled & 78 (76.5) & $24(23.5)$ & $102(100.0)$ & & Significant \\
\hline Unskilled & $64(25.2)$ & $190(74.8)$ & $254(100.0)$ & & \\
\hline \multicolumn{6}{|l|}{ Custodian } \\
\hline Parents & $240(52.5)$ & $217(47.5)$ & $457(100.0)$ & \multirow[t]{2}{*}{10.46} & 0.001 \\
\hline Guardian/relatives & $15(28.8)$ & 37 (71.2) & $52(100.0)$ & & Significant \\
\hline \multicolumn{6}{|l|}{ Religion } \\
\hline Christianity & $161(66.5)$ & $81(33.5)$ & $242(100.0)$ & \multirow[t]{2}{*}{53.32} & 0.0001 \\
\hline Islam & $94(34.8)$ & $176(65.2)$ & $270(100.0)$ & & Significant \\
\hline
\end{tabular}


schools (15, 78.9\%); 230 (53.6\%) and 199 (46.4\%) in private and public schools, respectively, felt that their figures were smart/fine/normal. Satisfaction with body figure was 199 (49.0\%) and 207 (51.0\%) in private and public schools, respectively, while dissatisfaction with body figure occurred more among respondents in private schools (23, $79.3 \%$ ). The school type of the respondents had a significant association with their perception of their figures $\left(\chi^{2}=4.71 ; \mathrm{P}=0.03\right)$, their satisfaction with their figures $\left(\chi^{2}=9.94 ; \mathrm{P}=0.002\right)$ and their fear about being overweight or obese $\left(\chi^{2}=4.25 ; \mathrm{P}=0.039\right)$.

Using the BMI, the majority of the girls from private schools were underweight (52.0\%), 10 (4.0\%) were overweight and $3(1.2 \%)$ were obese. For public schools, the majority (55.4\%) fell within the normal group, 6 (2.3\%) were overweight and none was obese. This weight classification using BMI had a significant association with the school type $\left(\chi^{2}=10.85\right.$; $\mathrm{P}=0.013)$. When the socio-demographic characteristics of respondents were cross tabulated against weight classification using BMI, there were significant associations with age $\left(\chi^{2}=42.76 ; \mathrm{P}=0.000\right)$ and mothers' occupation $\left(\chi^{2}=18.996 ; \mathrm{P}=0.004\right)$ (Table 4).

\section{Discussion}

The significant association between the school type and many of the socio-demographic characteristics of respondents underscores the fact that they are from different socio-economic backgrounds with the girls from private schools being significantly younger and more from monogamous family types. For their parents' occupations, the parents of the girls from private schools were more likely to be professionals compared to those from public schools who were more often unskilled workers. This clearly illustrates that the adolescents attending private schools were from richer and more enlightened homes on average when compared with their colleagues from public schools.

About two-thirds of students who had good knowledge about obesity were from private schools while two-thirds of students who had poor knowledge about obesity were from public schools and this association was found to be significant. This may be expected as the adolescents in private schools are from more enlightened families with better educated parents and, thus, may have better exposure to information at home, coupled with the fact that private schools are usually less populated, better organised and hence may offer better qual ity training than public schools. Unhealthy dietary practice, however, was found in about
Table 2. Risk factors for obesity in the respondents.

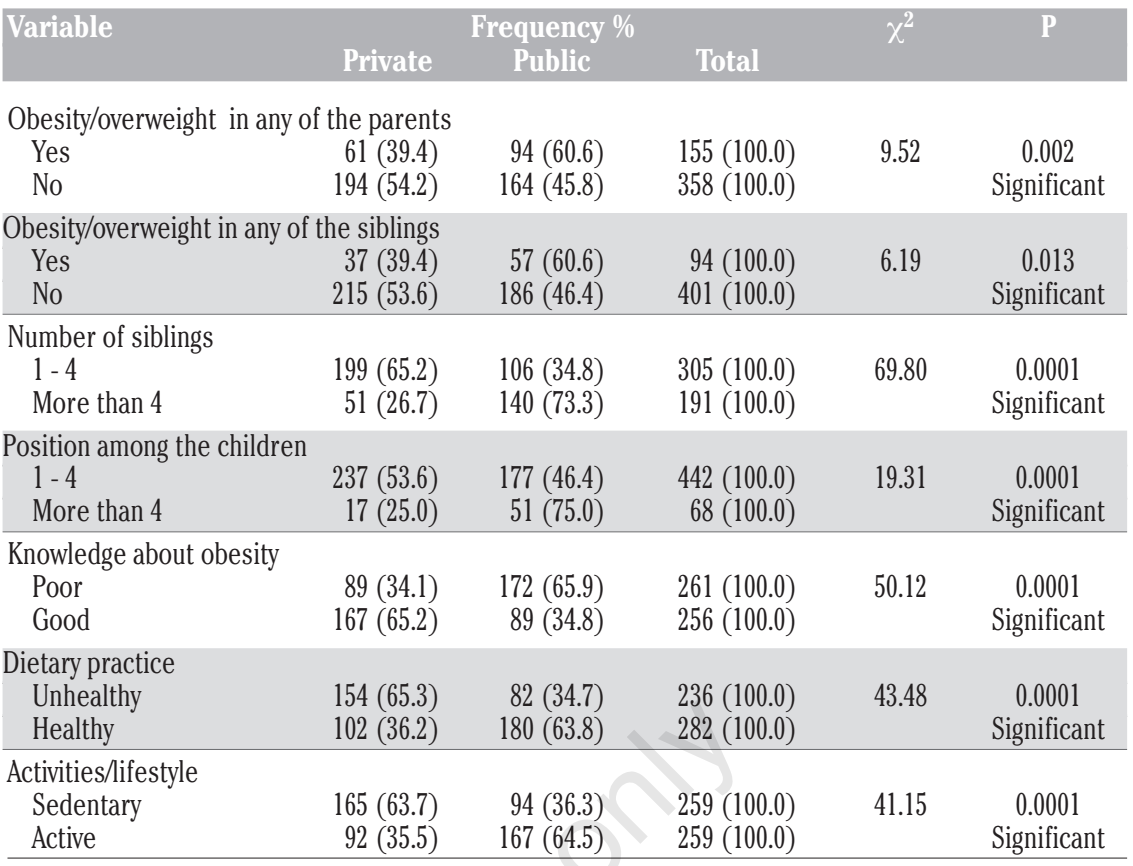

Table 3. Perception of respondents about obesity.

\begin{tabular}{|c|c|c|c|c|}
\hline Variable & $\begin{array}{l}\text { requency } \\
\text { Public }\end{array}$ & Total & $\chi^{2}$ & $P$ \\
\hline $\begin{array}{lr}\text { Self perception of own figure } \\
\text { Too fat } & 15(78.9) \\
\text { Okay/smart/normal } & 230(53.6)\end{array}$ & $\begin{array}{r}4(21.1) \\
199(46.4)\end{array}$ & $\begin{array}{r}19(100.0) \\
429(100.0)\end{array}$ & 4.71 & $\begin{array}{c}0.030 \\
\text { Significant }\end{array}$ \\
\hline $\begin{array}{lr}\text { Satisfied with figure } & \\
\text { Yes } & 199(49.0) \\
\text { No } & 23(79.3) \\
\end{array}$ & $\begin{array}{r}207(51.0) \\
6(20.7) \\
\end{array}$ & $\begin{array}{r}406(100.0) \\
29(100.0)\end{array}$ & 9.94 & $\begin{array}{c}0.002 \\
\text { Significant }\end{array}$ \\
\hline $\begin{array}{lr}\text { Peers making fun of your figure } \\
\text { Yes } & 101(55.5) \\
\text { No } & 152(49.4)\end{array}$ & $\begin{array}{r}81(44.5) \\
156(50.6)\end{array}$ & $\begin{array}{l}182(100.0) \\
308(100.0)\end{array}$ & 1.73 & $\begin{array}{c}0.189 \\
\text { Not significant }\end{array}$ \\
\hline $\begin{array}{lr}\text { Scared about being overweight/obes } \\
\text { Yes } & 143(47.7) \\
\text { No } & 106(57.3)\end{array}$ & $\begin{array}{r}157(52.3) \\
79(42.7)\end{array}$ & $\begin{array}{l}300(100.0) \\
185(100.0)\end{array}$ & 4.25 & $\begin{array}{c}0.039 \\
\text { Significant }\end{array}$ \\
\hline
\end{tabular}

Table 4. Cross-tabulation of socio-demographic characteristics of respondents against body mass index groupings.

\begin{tabular}{|c|c|c|c|c|c|c|}
\hline Variable & Under-weight & $\begin{array}{c}\text { Grouping } \\
\text { Normal }\end{array}$ & $\begin{array}{l}\text { for BMI \% } \\
\text { Over-weight }\end{array}$ & Obesity & Total & $\chi^{2}$ \\
\hline $\begin{array}{l}\text { School type } \\
\text { Private } \\
\text { Public }\end{array}$ & $\begin{array}{l}131(52.0) \\
110(42.3)\end{array}$ & $\begin{array}{l}108(42.9) \\
144(55.4)\end{array}$ & $\begin{array}{r}10(4.0) \\
6(2.3)\end{array}$ & $\begin{array}{l}3(1.2) \\
0(0.0)\end{array}$ & $\begin{array}{l}252(100.0) \\
260(100.0)\end{array}$ & $\begin{array}{cc}10.85 & 0.013 \\
& \text { Significant }\end{array}$ \\
\hline $\begin{array}{c}\text { Age groups (yr) } \\
10-14 \\
15-19 \\
\end{array}$ & $\begin{array}{r}166(60.4) \\
75(31.6)\end{array}$ & $\begin{array}{l}103(37.5) \\
149(62.9)\end{array}$ & $\begin{array}{r}5(1.8) \\
11(4.6)\end{array}$ & & $\begin{array}{l}275(100.0) \\
237(100.0)\end{array}$ & $\begin{array}{cc}42.76 & 0.000 \\
& \text { Significant }\end{array}$ \\
\hline $\begin{array}{l}\text { Religion } \\
\text { Christianity } \\
\text { Islam }\end{array}$ & $\begin{array}{l}111(47.0) \\
126(47.0)\end{array}$ & $\begin{array}{l}120(50.8) \\
128(47.8)\end{array}$ & $\begin{array}{r}4(1.7) \\
12(4.5)\end{array}$ & $\begin{array}{l}1(0.4) \\
2(0.7)\end{array}$ & $\begin{array}{l}236(100.0) \\
268(100.0)\end{array}$ & $\begin{array}{l}3.520 .318 \\
\text { Not significant }\end{array}$ \\
\hline $\begin{array}{c}\text { Family setting } \\
\text { Monogamous } \\
\text { Polygamous } \\
\end{array}$ & $\begin{array}{r}191(49.4) \\
43(38.7) \\
\end{array}$ & $\begin{array}{r}179(46.3) \\
66(59.5)\end{array}$ & $\begin{array}{r}14(3.6) \\
2(1.8)\end{array}$ & $\begin{array}{l}3(0.8) \\
0(0.0)\end{array}$ & $\begin{array}{l}387(100.0) \\
111(100.0)\end{array}$ & $\begin{array}{lc}6.87 & 0.076 \\
& \text { Not significant } \\
\end{array}$ \\
\hline $\begin{array}{l}\text { Father's occupa } \\
\text { Skilled } \\
\text { Semi-skill } \\
\text { Unskilled }\end{array}$ & $\begin{array}{l}\text { tion } \\
\qquad \begin{array}{r}119(51.1) \\
67(51.1) \\
51(37.5)\end{array}\end{array}$ & $\begin{array}{r}105(45.1) \\
60(45.8) \\
79(58.1)\end{array}$ & $\begin{array}{l}7(3.0) \\
3(2.3) \\
6(4.4)\end{array}$ & $\begin{array}{l}2(0.9) \\
1(0.8) \\
0(0.0)\end{array}$ & $\begin{array}{l}233(100.0) \\
131(100.0) \\
136(100.0)\end{array}$ & $\begin{array}{cc}9.29 & 0.157 \\
& \text { Not significant }\end{array}$ \\
\hline $\begin{array}{l}\text { Mother's occupa } \\
\text { Skilled } \\
\text { Semi-skill } \\
\text { Unskilled }\end{array}$ & $\begin{array}{l}\text { ation } \\
\qquad 70(46.7) \\
64(63.4) \\
104(41.4)\end{array}$ & $\begin{array}{r}72(48.0) \\
32(31.7) \\
141(56.2)\end{array}$ & $\begin{array}{l}7(4.7) \\
4(4.0) \\
5(2.0)\end{array}$ & $\begin{array}{l}1(0.7) \\
1(1.0) \\
1(0.4)\end{array}$ & $\begin{array}{l}150(100.0) \\
101(100.0) \\
251(100.0)\end{array}$ & $\begin{array}{cc}18.996 & 0.004 \\
& \text { Significant }\end{array}$ \\
\hline
\end{tabular}


two-thirds of girls from private schools whereas more than six out of 10 girls who had healthy dietary practices were from public schools. This knowledge-behaviour gap may be owing to the fact that the girls attending private schools, because of better economic status, have an increased likelihood of having Western diets and eating junk-foods than their counterparts in public schools. Furthermore, about threefifths of the girls who lived sedentary lifestyles were from private schools while about twothirds of those who lived active lifestyles were from public schools and these associations were also found to be statistically significant. This can be understood, considering the fact that most of the students at private schools were from relatively richer homes where most house chores will be carried out by housemaids; they also have ready access to cars, which encourage a more sedentary lifestyle.

Using the BMI, the prevalence of being overweight and of obesity was higher among the girls from private schools, being $4.0 \%$ and $1.2 \%$, and $2.3 \%$ and $0 \%$, respectively. The difference in this prevalence in private and public schools may be because of the poor healthy dietary practice and the sedentary lifestyles of the students from private schools, because these have been strongly linked to the pathogenesis of obesity. ${ }^{15-18}$ The prevalence is similar to what has been reported in different parts of the country. ${ }^{28-30}$ This prevalence, however, is very low compared to figures from other parts of the world, ${ }^{8,10,24-27}$ and this may be owing to the fact that there is still widespread poverty in Nigeria with about $70 \%$ of the population still living below the international poverty line of 1.25 US dollars a day. ${ }^{34}$

However, it is quite surprising that about half of the girls from private schools were underweight. This may be owing to the fact that many of these girls from above average families may, by reason of exposure or travel, have been attracted to the Western beauty figure of a slim lady and may intentionally modify their diets so as to fit the Western beauty figure. This may also explain the reason why significantly more girls in private schools felt they were too fat and one out of 10 of them was dissatisfied with her figure, as compared to those at public schools, where almost all of the girls were satisfied with their figures. This brings to mind the issue of anorexia nervosa, which is found mainly in the developed countries but has been reported also in sub-Saharan Africa. ${ }^{35,36}$ This may be a subject for further research.

\section{Conclusions}

The girls from private schools had a better knowledge about obesity but had more unhealthy dietary practices and lived more sedentary lifestyles as compared to their colleagues from public schools who had poorer knowledge about obesity but had healthier dietary practices and lived more active lifestyles. Consequently, the prevalence of being overweight and of obesity was higher among the girls at private schools than among girls attending public schools. Parents and teachers should be encouraged to promote a healthy balance of food, drink and physical activity within and outside the school. It is also recommended that enlightenment programmes on obesity targeted at adolescents should take their different socio-economic backgrounds into consideration to be effective.

\section{References}

1. Peter G. Meeting the sexual health needs of young people. Population concensus, 1999, pp 5-10.

2. Chin YS, Mohd Nasir MT. Eating behaviours among female adolescents in Kuantan, Pahang, Malaysia. Pakistan J Nutr 2009;8:425-32.

3. John D, Catherine T. Guidelines for comprehensive sexuality education in Nigeria. AHI, 2003, pp 4-9.

4. Shi Z, Lien N, Kumar BN, HolmboeOttesen G. Socio-demograghic differences in food habits and preferences of school adolescents in Jiangsu province, China. Eur J Clin Nutr 2005;59:1439-48.

5. Savage GS, Ball K, Worsley A, Crawford D. Food intake patterns among Australian adolescents. Asia Pac J Clin Nutr 2007;16:738-47.

6. WHO. The management of nutrition in major emergencies. World Health Organisation, Geneva, 2000.

7. World Health Organization. Obesity: preventing and managing the global epidemic. Report of a WHO consultation. World Health Organisation, Geneva, 1998.

8. Tremblay MS, Willms JD. Secular trends in the body mass index of Canadian children. CMAJ 2000;163:1429-33.

9. Reilly J. Epidemic of obesity in UK children. Lancet 1999;354:1874-5.

10. Dietz WH. Health consequences of obesity in youth: childhood predictors of adult disease. Pediatrics 1998;101:518-25.

11. De Onis M, Blössner M. Prevalence and trends of overweight among preschool children in developing countries. Am J Clin Nutr 2000;72:1032-9.

12. Samuelson G. Dietary habits and nutritional status in adolescents over Europe. An overview of current studies in the Nordic countries. Eur J Clin Nutr 2000; 54:S21-8.
13. bin Zaal AA, Musaiger A0, D'Souza R. Dietary habits associated with obesity among adolescents in Dubai, United Arab Emirates. Nutr Hosp 2009;24:4.

14. Schneider D. International trends in adolescent nutrition. Soc Sci Med 2000;51: 955-67.

15. Sallis JF, Glanz K. The role of built environments in physical activity, eating, and obesity in childhood. Future Child 2006;16:89-108.

16. Musaiger A0. Diet and prevention of coronary heart disease in the Arab Middle East countries. Med Princ Pract 2002;11: S9-16.

17. Anderson PM, Butcher KF. Childhood obesity: trends and potential causes of childhood obesity. Future Child 2006;16:19-45.

18. Jebb SA, Moore MS. Contribution of a sedentary lifestyle and inactivity to the etiology of overweight and obesity: current evidence and research issues. Med Sci Sports Exerc 1999;31:S534-41.

19. Ojofeitimi EO, Adeyeye AO, Fadiora AO, et al. Awareness of obesity and its health hazards among women in a university community. Pakistan J Nutr 2007;6:502-5.

20. Freedman DS, Dietz WH, Srinivasan SR, Berenson GS. The relation of overweight to cardiovascular risk factors among children and adolescents: The Bogalusa Heart Study. Pediatrics 1999;103:1175-82.

21. Whitaker AH. An epidemiological study of anorexic and bulimic symptoms in adolescent girls. Implication of paediatrician. Paediatrics 1992;21:752-9.

22. Wadden T, Stunkard A. Social and psychological consequences of obesity. Ann Intern Med 1985;103:1062-7.

23. Strauss RS. Childhood obesity and selfesteem. Paediatrics 2000;105:1-5.

24. Troiano RP, Flegal KM. Overweight children and adolescents; Description, epidemiology and demographic. Paediatrics 1998;101:510-25.

25. Baur LA. Review article: child and adolescent obesity in the 21st century: An Australian perspective. Asia Pac J Clin Nutr 2002;11:S524-8.

26. Westerbeek H, Smith A. Corporate social responsibility and community health in the UAE: The case of the Al Jazira sport and health foundation. MEJB 2005;1. Available at www.mejb.com/upgrade_ flash/Vol1_Issue1/Corporate-SocialResponsibility.htm

27. Al-haddad FH, Bertis LB, Ghafar AGAM. Childhood obesity in United Arab Emirates schoolchildren: A national study. Ann Hum Biol 2005;32:72-9.

28. Omolola A, Kara E, Olayemi 00, et al. Relative height and weight among children and adolescents of rural south-western Nigeria. Ann Hum Biol 2009;36:388-99.

29. Ben-Bassey UP, Oduwole AO, Ogundipe 
00. Prevalence of overweight and obesity in Eti-Osa LGA, Lagos, Nigeria. Obesity Rev 2007;8:475-9.

30. Victor OA, Maxwell UA, Wilfred ON. Soft drink consumption and overweight/obesity among Nigerian adolescents. CVD Prevention and Control 2008;3:191-6.

31. Woodruff BA. Assessment of the nutritional status of adolescents in emergency affected populations. Centres for Disease Control and Prevention, Atlanta. RNIS Suppl 2000, pp 1-21.
32. World Health Organisation. Nutrition in Adolescence - Issues and challenges for the health sector: Issues in adolescent health and development. WHO, Geneva, 2005.

33. Araoye M0. Research Methodology with Statistics for Health and Social Sciences. Nathadex Publishers, 2004, pp 115-21.

34. UNICEF. At a Glance: Nigeria. Accessed from the official Website of UNICEF: www.unicef.org (Accessed on 7th November, 2009).
35. Bennett D. Anorexia nervosa among female secondary school students in Ghana. Br J Psychiatr 2004;185:312-7.

36. Isevbigie TI, Owie I. Eating disorders and personality profile of female secondary schools students in Benin Metropolis, Nigeria. J Instruct Psychol 2006;3. Available at: http://www.freepatentsonline.com/article/Journal-InstructionalPsychology/157946272.html 